\title{
The Future Of Online Courses: How To Win The Marketing War
}

Rodney P. Riegle, (E-mail: rpriegle@ilstu.edu), Illinois State University

\begin{abstract}
Many colleges are looking to online education to improve their revenue stream. Competition for online students is escalating. Designing online courses like video games can help win the marketing war.
\end{abstract}

\section{INTRODUCTION}

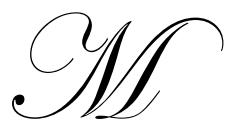

ore and more students shop for courses that best accommodate their schedules and learning styles, and then transfer the credit to the school or university where they will earn their degrees. Nearly $80 \%$ of all U.S. students graduating with a baccalaureate degree have "attended" two or more institutions. ${ }^{1}$ The advent of online education has facilitated this shopping phenomenon.

Online course offerings are becoming increasingly more common in education. Nearly three million U.S. students are currently taking university level courses online and more than half of all higher education institutions see online education as critical to their long-term strategy. Moreover, a majority of academic leaders believe that the quality of online courses is already equal or superior to face-to-face courses. ${ }^{2}$ The competition for online students will continue to escalate as more and more institutions realize that online education is a fast-growing, multi-billion dollar market. ${ }^{3}$

Clearly, education is becoming a commodity and many educational institutions are looking to online education to improve their revenue stream. The competition for online students is bound to become more and more intense. The marketing of online courses, however, is still in its infancy. Courses designed like video games are one way to win this competition by appealing to the target demographic in a way that they embrace. A recent study found that seventy percent of U.S. college students play video games (thirty-two percent even admit to playing video games during class without the knowledge of their instructors). ${ }^{4}$

\section{VIDEO GAMES}

The industry statistics on video games are both staggering and revealing:

- $\quad$ Fifty percent of all Americans age six and older play computer and video games.

- $\quad$ Ninety-two percent of all games are purchased by adults over the age of 18 .

- $\quad$ The average age of a game player is 29 years old.

- $\quad$ Thirty-nine percent of game players are women.

- In 2003, over 239 million computer and video games were sold, or almost two games for every household in America.

- $\quad$ Fifty-six percent of the most frequent computer and video game players have been playing games for six or more years, while 60 percent expect to be playing games as much or more ten years from now as they do today.

- $\quad$ Video games ( $\$ 12$ billion annually) have now passed movies (\$8 billion annually) as the most popular form of entertainment in the U.S. ${ }^{5}$ 
Those educational institutions who encourage their instructors and instructional designers to harness this video gaming phenomenon, and provide the resources necessary to do so, will clearly gain a tactical advantage over their competitors.

\section{ONLINE RPGS}

In addition to being one of the most popular video game genres (along with adventure and sports), RPGs are perhaps the most appropriate video game genre for educational purposes. RPG stands for Role-Playing Game. A role-playing game is a game in which each player takes the part of a character and participates in an adventure. Dungeons and Dragons ${ }^{6}$ is one example of a popular role-playing game (originally played in-person with dice) set in a medieval fantasy world. Oregon Trail, ${ }^{7}$ where students take the role of nineteenth century pioneers in the American west, is one early example of an educational RPG (originally played via a CD on a computer). The popularity of online role-playing games is as staggering and revealing as the previous statistics on video games. There are currently more than 25 million people playing MMORPGs ${ }^{8}$ (Massively Multiplayer Online Role-Playing Games): ${ }^{9}$

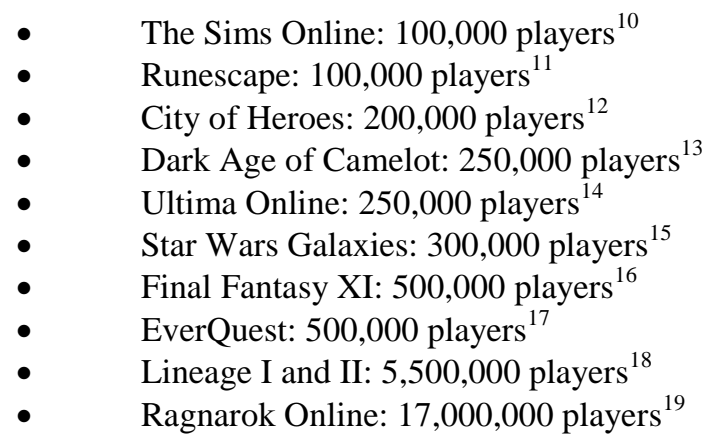

Since each of these MMORPGs requires a monthly subscription fee (usually $\$ 10-15$ ) to play, there is clearly something fundamentally attractive about online RPGs. Moreover, the attraction is both global and crosscultural and transcends age and gender differences, perhaps due to the multi-faceted nature of the motivations of MMORPG players. ${ }^{20}$

\section{EDUCATIONAL GAMES}

Educational games are nothing new. A quick search of the U.S. Department of Education's Education Resources Information Center (ERIC) database ${ }^{21}$ yielded over 15,000 results for the keyword games. Playing video games is also not new; it has now been over 20 years since ATARI ${ }^{22}$ claimed its first addicts. The advantages of online educational video games include:

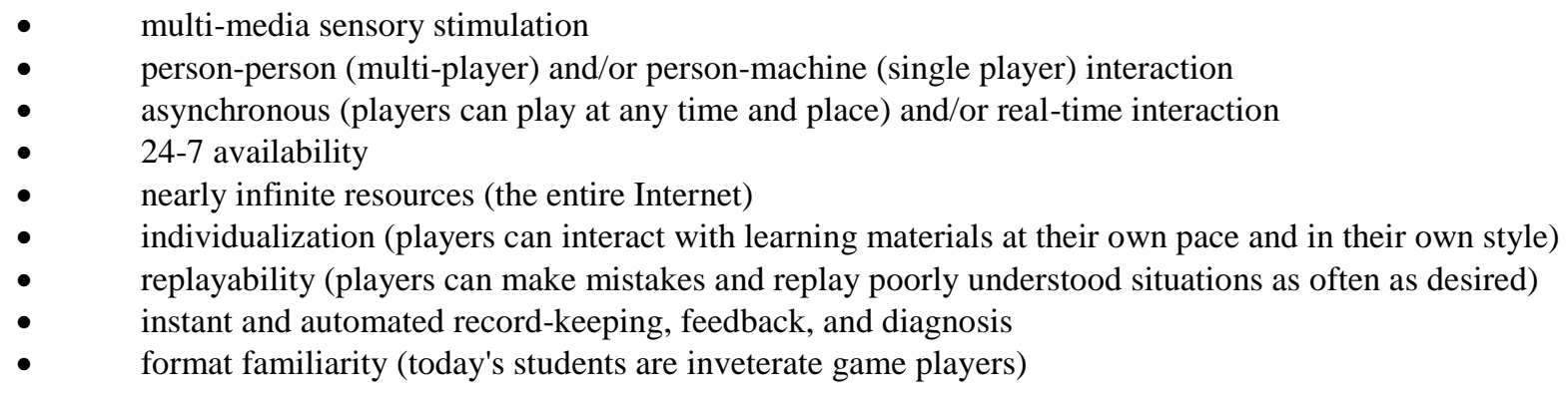

Because video games are still in their infancy both technically and conceptually, most are not educational. Do not be misled by this. Video games constitute a new and as yet poorly developed instructional form that holds great promise for both designers and players. The idea of using video games as to teach is admittedly controversial. Some educators believe that academic content cannot be transmitted through video games. Others believe video 
games have no connection to the real world. Still others believe that video games are violent and encourage antisocial behavior. However, two bestselling video games, Civilization ${ }^{23}$ and SimCity $^{24}$, are already being used in college classrooms to teach history and urban planning respectively and the entire field of video gaming is beginning to gain academic credibility. ${ }^{25}$

\section{OBSTACLES}

Unfortunately, most educators have little understanding of either technology or gaming while most technologists and gamers have no background in education. Thus, the conceptual obstacles are at least as profound as the technical ones. This is a common phenomenon during paradigm shifts.

For example, the first movie makers placed cameras in the pit of a theater and filmed stage plays. Eventually, they realized that they were allowing the structures of the older art form to limit their use of the new technology. Then, and only then, were they able to develop new techniques and an entirely new art form. Predictably, a review of online courses reveals that almost all can be characterized as electronic versions of the old instructional paradigm limited primarily by the inability of their creators to throw off the mental shackles of the Industrial Age classroom.

The ultimate revolution in instructional design may have to wait until today's students, who have never known a time without video games or the Internet, become tomorrow's teachers. In the meantime, today's teachers would clearly benefit from exposure to video game design theory and collaboration with video game designers. Efforts like The Education Arcade, a consortium of international video game designers, publishers, scholars, educators, and policy makers, are a harbinger of the future of instructional design. ${ }^{26}$

\section{CONCLUSION}

Humor, mystery, adventure--these are essential characteristics of Information Age courses. In the not-toodistant future, it will be common practice for courses to be designed like RPG video games. In a global economy dominated by the video game generation, edutainment will inevitably supercede both education and entertainment. Some people believe that the merger of education and entertainment will diminish education. To the contrary, and perhaps more importantly, it will improve entertainment. Since typical students spend nearly as much time playing video games (10,000 hours by the time they graduate) as they do in class, this is an exceedingly important goal.

In the year 2000, I designed the world's first online course (EAF $228^{27}$ ) that was an educational RPG video game and since then more than 1,000 students have taken it. In the past, EAF 228 would perhaps be viewed as a mildly amusing course that had no real application to other settings. However, with the advent of the global Internet students anywhere in the world can now take my course and transfer the credit to their university. And you should note that I have had online students from every continent except Antarctica; all of whom generated credits for my university.

The moral is that video games are no longer just games. They are an important tool in the creation of effective learning environments and they are a crucial weapon in the inevitable online learning marketing war. The first battle for the future of online courses has already begun at EAF 228. The marketing war is about to escalate. Designing online courses like video games and utilizing video game marketing strategies (e.g., movie trailers, screen shots, etc.) would be a shrewd strategy for those institutions that are looking for ways to mount an effective marketing campaign.

\section{ENDNOTES}

1. Adelman, C. “Answers in the Toolbox: Academic Intensity, Attendance Patterns, and Bachelor's Degree Attainment." United States Department of Education. June 1999. 1 November 2004 http://www.ed.gov/ pubs/Toolbox/index.html. 
2. Allen, I. Elaine and Seaman, Jeff. "Entering the Mainstream: The Quality and Extent of Online Education in the United States, 2003 and 2004." The Sloan Consortium. November 2004. 1 November 2004 http://www.sloanc.org/resources/entering_mainstream.pdf .

3. Greenspan, Robyn. "Reading, Writing, Pointing-and-Clicking." ClickZStats. 18 July 2003. 1 November 2004 http://cyberatlas.internet.com/markets/education/article/0,5951_2237481,00.html.

4. Jones, Steve. "Let the games begin: Gaming technology and entertainment among college students." Pew Internet \& American Life Project, 6 July 2003. 1 November 2004 http://www.pewinternet.org/ reports/toc. asp?Report $=93$.

5. $\quad$ Entertainment Software Association. "The Essential Facts About the Computer and Video Game Industry." 12 May 2004. 1 November 2004 http://www.theesa.com/EFBrochure.pdf.

6. Dungeons \& Dragons Roleplaying Game Official Home Page. 1 November 2004<http://www.wizards.com/dnd/.

7. The Oregon Trail $5^{\text {th }}$ Edition. Broderbund. 1 November $2004<$ http://www.broderbund.com/ jump.jsp?itemID=147\&mainPID=147\&itemType=PRODUCT\&path=1\%2C2\%2C8\%2C67\&iProductID=147.

8. Woodcock, Bruce. "An Analysis of MMOG Subscription Rates." 1 November 2004 http://pw1.netcom.com/ sirbruce/Subscriptions.html.

9. For more information on MMORPGs, see "MMORPG." Wikipedia. 1 November 2004 http://en.wikipedia.org/wiki/MMORPG.

10. "The Sims Online." Electronic Arts. 1 November 2004 <http://www.eagames.com/official/thesims/ thesimsonline/us/nai/index.jsp.

11. "Runescape." Jagex Ltd. 1 November 2004 http://www.runescape.com/.

12. "City of Heroes.” NCsoft. 1 November 2004 http://www.cityofheroes.com/.

13. "Dark Age of Camelot." Mythic Entertainment. 1 November 2004 http://www.darkageofcamelot.com/.

14. "Ultima Online." Electronic Arts. 1 November 2004 http://www.uo.com/.

15. "Star Wars Galaxies.” Sony. 1 November 2004 http://starwarsgalaxies.station.sony.com/.

16. "Final Fantasy XI." Square Enix. 1 November 2004 http://www.playonline.com/ff11us/index.shtml.

17. "EverQuest." Sony. 1 November 2004 http://eqlive.station.sony.com/.

18. “Lineage.” NCsoft. 1 November 2004 http://www.ncsoft.net/eng/ncgames/lineage_intro_01.asp.

19. "Rognarok Online." Gravity Corp. 1 November 2004 http://www.ragnarokonline.com/.

20. Yee, Nicholas. "Facets: 5 Motivation Factors for Why People Play MMORPG's." 1 November 2004 http://www.nickyee.com/facets/home.html.

21. ERIC: Educational Resource Information Center. United States Department of Education. 1 November 2004 http://www.eric.ed.gov/.

22. For more information on Atari, see the online Atari Museum at http://www.atarimuseum.com/.

23. Civilization III: Home. 1 November 2004 http://www.civ3.com/.

24. SimCity 4. 1 November 2004 http://simcity.ea.com/.

25. For more information on The Education Arcade, see their website at http://www.educationarcade.org/.

26. For more information on video games in the classroom see Carlson, Scott. "Can Grand Theft Auto Inspire Professors?" The Chronicle of Higher Education, 15 August 2003. 1 November 2004 http://chronicle.com/free/v49/i49/49a03101.htm\#101.

27. Riegle, Rodney. "EAF 228: Social Foundations of Education." Illinois State University. 1 November 2004 <http://www.coe.ilstu.edu/rpriegle/eaf228/>. This course was featured in the November 3, 2003 AACTE Briefs available online at http://www.aacte.org/Research/focus_tech_game.htm. The course title of EAF 228 is Social Foundations of Education. It was the world's first online course for teachers (1994) and the world's first online course-game (2000). The content of EAF 228 is history/philosophy/sociology of education (with a focus on information technology and the future). Its target is undergraduate teacher education majors (all grade levels and specialties) and it is offered every semester including summer. Enrollment is 100 students per semester (over 3,000 since 1994). EAF 228 is totally online (no meetings, no paper materials or texts) and asynchronous (independent of space and time). It utilizes collaborative learning (via a voluntary discussion board), mastery learning (student controlled pace and amount), multi-media (text, images, sound, music, video), video game design principles (story, quests, characters, map, voices, player's guide, etc.), automated online record keeping for the instructor (via ASP and an Access database), automated online feedback and progress reports for students (both individual and collective), standard HTML platform (designed and maintained by the instructor since 1994), no commercial products (such as WebCT or Blackboard). Visitors are encouraged to login and browse any or all parts of the course. 